\title{
JESTIANALYSIS OF CICERO'S ORATIO IN CATILINAM PRIMA FROM THE ASPECT OF PHONOSTYLISTICS AND LEXICOSTYLISTICS
}

\section{Sanja Merzić ${ }^{1}$}

Faculty of education Mostar

Received: 08.04.2013.

Accepted: 22.04.2013.
Original scientific paper

UDC: 808.5

\begin{abstract}
This work represents an analysis of Cicero's speech Oratio in Catilinam Prima on two levels: phonostylistic and lexicostylistic with the goal to represent expressive voice function and figures of speech on phonostylistic level and to represent lexic with additional meaning, relations between words and lexico-syntactic figures on lexicostylistic level. Also, the purpose of the speech is to show what makes Cicero's speeches specific and successful.
\end{abstract}

Key words: Cicero, Catiline, analysis, phonostylistics, lexicostylistics, vocals, consonants, assonance, alliteration, professionalisms, antonyms, synonyms, paronyms, figures of speech.

\section{INTRODUCTION}

The first question that comes to mind is why did we choose this topic? Firstly, because no one else in the linguistic space of $\mathrm{B} \& \mathrm{H}$, as far as our acknowledgment goes, had explored phonostylistic or lexicostylistic level of this Cicero's speech. Also, there was a certain amount of curiosity which aspired to realize what is in Cicero's language that made him famous and unavoidable name in the history of oratory, who was Cicero, what is the art of speaking and is it really possible to change the opinion of a group and to make it do good by using the art mentioned above. In the truthfulness of the last we have been assured by Cicero namely because of this speech and three other that followed Catiline and his followers were banished from the state and the purpose of his speeches was achieved.

On the level of phonostylistics we have explored ex- pressive voice function and figures of speech that appear on this level. On the level of lexicostylistics our exploration was focused on lexic with additional meaning, relations between words and lexico-syntactic figures.

\section{PHONETIC LEVEL OF ANALYSIS}

As we have mentioned in the introduction, on this level of analysis we have researched expressive voice function or use of vocals of front/final row, high/low vocals and opened/closed vocals. These three divisions are made based on the position of tongue during their pronunciation (first and second division) and based on the size of lip opening during their pronunciation (third division). 
First division is defined based on the differences in horizontal position of tongue (for moving back-forward) while the other division proceeds from differences in vertical position of tongue (his moving updown) (Jahić, Halilović i Palić, 2000, p. 88)².

One vocal that has special expressive function is „, 0 . It is a vocal of final row, middle vocal and middle opened vocal. This vocal is used in words that build anaphora, which contributes to the intensity of emotions and therefore expressiveness (dokle, želeo, koliko). This can be seen in the examples that follow:

„Dokle ćeš već, Katilino, zloupotrebljavati naše strpljenje? Dokle li ćeš nas još izazivati svojim besom? Dokle će se razmetati tvoja neobuzdana drskost?" (Avramović, 2009, p. 464)

„Želeo bih, oci senatori, da budem blag; želeo bih da se prema ovim državnim opasnostima ne pokažem ravnodušan, ali, eto, već sam sebe osuđujem zbog slabosti i nerada." (Avramović, 2009, p. 465)

„Koliko li si samo puta pokušavao mene da ubiješ kao izabranoga a koliko puta kao pravoga konsula. Koliko li sam tvojih zaseda, tako udešenih da im je izgledalo nemoguće izbeći, izbegao ja malim kakvim pokretom ili obrtom tela. (...) Koliko li ti je puta istrgnut mač iz ruku a koliko li puta je sam, slučajem, ispuštan?“ (Avramović, 2009, p. 468)

In relation to expressive voice function lays the use of figures of speech. The once we have found and that appear on this level are assonance and alliteration.

\section{ASSONANCE}

Assonance is defined as repetition of same vocals or vocals of the same type - for example frontal or final in a certain segment of text, with a goal of creating voice symbolism, harmony or association to a key or thematic word of that text (Katnić-Bakaršić, 2007, p. 304).

Examples of assonance found in the analyzed speech are:

„Predaću te smrti tek onda kad se ne bude mogao naći niko toliko nečastan, toliko propao, toliko sličan tebi, koji ne bi priznao da je to pravedno urađeno." (Avramović, 2009, p. 465)

„Kad je to tako, Katilino, nastavi i idi putem kojim si pošao, izađi već jednom iz grada. Otvorena su ti vrata. Idi! Odavno te već očekuje kao vođu onaj tvoj manliski logor. Izvedi sa sobom sve svoje, izvedi ih koliko god možeš više, te očisti grad.“" (Avramović, 2009, p. 467)

\section{ALLITERATION}

Alliteration is repetition of same consonants or consonants of the same type in a text, with the same goal as assonance (Katnić-Bakaršić, 2007, p. 304). Examples of alliteration found in the analyzed speech are:

„A mi već dvadesetdanadopuštamoda slabi i da se gasi snaga odluke većnika.“ (Avramović, 2009, p. 465)

„I zar, kad si se u same novembarske kalende nadaonoćnimnapadom zauzeti Prenestu - nisi zar uvideo da je ta naseobina utvrđena po mojoj zapovesti, mojom odbranom, mojom posadom, mojom stažom?““ (Avramović, 2009, p. 466)

At the end of phonostylistic analysis we must say we have found more examples of assonance and alliteration but as a consequence of lack of space we couldn't have mentioned all.

\section{LEXICAL LEVEL OF ANALYSIS}

\section{Lexic with additional meaning}

When analyzing lexic with additional meaningwe have focused on professionalisms. Whileanalyzingprofessionalisms we have noticed they can be divided in two groups: the ones belonging to legislative power and the ones characteristic for military. We will mention only few from both groups.

Legislative power:

senat (senat, senatskog veća, senatsku odluku, senatskim rešenjem, oci senatori),

država (država, državno stanje, državno rešenje, državnom zaštitom, državnih interesa).

Military:

objekte vršenja radnje (neprijatelj, vođu, saveznika, pristalica, razbojnika),

mjesta vršenja radnje (tabor, u okove, u tamnicu, izgnanstvo).

\section{Relations between words}

There are three types of relations between words in the analyzed speech: antonymy, snonymy and paronymy. We will give definitions and examples of all three.

Antonyms are words that have extremely opposite meaning (Sarić in print, p. 33).In the speech we have these antonyms: umanjiš - ojačaš, ostati - udaljiti, ćute - viču, ne vide - gledaju, spasenjem - propašću.

${ }^{2}$ All definitions were translated by the author. 
Synonyms are words of the same meaning, and different phonemic system (Saric in print, p. 32). The ones found in the speech are: - paziće, čuvati; - sve izlazi na videlo, sve se obelodanjava; - mojom posadom, mojom stražom; - utvrdio, uglavio.

Paronyms or Derivates got their name because they are derived from the same root morpheme. In that way they form a family of words. Paronyms present in the speech are: straha, strahovati; siguran, sigurnost;uživati, uživanjem; razbojničko, razbojništvom; bolest, bolesnici, boluje.

\section{Lexico-syntactic figures}

Lexico-syntactic figures found in the speech are epithets, gradations, anaphoras, rhetorical questions, rhetorical conversions and exclamations, inversions and parallelisms. We are not able to define or give examples for all figures of speech because of insufficient space in the paper. Therefore, we have chosento mention those which are most common: anaphora and rhetorical question.

\section{ANAPHORA}

Anaphora implicates repetition of the same word or group of words at the beginning of two or more sentences, two or more verses, paragraphs ... (KatnićBakaršić, 2007, p. 309). We will only mention some anaphoras found in the speech:

„Dokle ćeš već, Katilino, zloupotrebljavati naše strpljenje? Dokle li ćeš nas još izazivati svojim besom? Dokle će se razmetati tvoja neobuzdana drskost?"“(Avramović, 2009, p.464)

„Ili te sprečavaju zakoni koji su propisani o pogubljenju rimskih građana? (...) Ili se bojiš osude potomstva? (...)Ili ti misliš da nećeš izgoreti vatrom osude, kada Italija bude opustošena, gradovi porušeni, a domove vam bude oganj požderao?" (Avramović, 2009, p. 471)

\section{RHETORICAL QUESTION}

Rhetorical question is a question which doesn't have an answer or the speaker isn't expecting it (KatnićBakaršić, 2007, p. 313). Rhetorical questions found in the speech are:
„Zar nije najslavniji muž, Publije Scipion, veliki sveštenik, kao privatna ličnost ubio Tiberija Graha, koji je pokolebao državno stanje? Zar ćemo mi, konzuli, trpeti Katilinu koji hoće pokoljem i požarima da opustoši zemlju?" (Avramović, 2009, p. 465)

„Šta je Katilino? Zar se ti kolebaš da učiniš po mome nalogu ono što si već svojevoljno radio?" (Avramović, 2009, p. 467)

„Kakvom ćeš tu radošću moći uživati; kakvim li se uživanjem ushićavati; u kakvom li zadovoljstvu plivati, kada u tolikom broju svojih pristalicane sretněs ni jednog čestitog čoveka?" (Avramović, 2009, p. 470)

Examples mentioned above are just „traces“of many rhetorical questions present in the speech.

\section{CONCLUSION}

Few important notes that we have to mention in the conclusion of our speech are:

Much more can be said on the topic of figures of speech that appear on both levels, especially on lexicostylistic level, if given enough space. Having finished phonostylistic analysis of the speech we can conclude that expressiveness is characteristic for this level of analysis. It is achieved using assonance and alliteration, and by repeating voice „, 0 ".

On the level of lexicostylistics we have discovered presence of professionalisms, antonyms, synonyms and paronyms as well as presence of many lexicosyntactic figures.

These features are just parts of what makes Cicero's language and speeches so successful and unavoidable. By the strength of his word, distinct pronunciation and specific forms Cicero became a role model for future orators.

\section{REFERENCES}

Avramović, S. (2009). Rhetorike techne: veština besedništva i javni nastup (2. Izdanje) [Rhetorike techne: art of oratory and public speaking (2nd Edition)]. Pravni fakultet Univerziteta: Službeni glasnik, Beograd.

Jahić, Dž., Halilović, S. i Palić, I. (2000). Gramatika bosanskoga jezika [Grammar Bosnian language], Zenica, B\&H: Dom štampe.

Katnić-Bakaršić, M. (2007). Stilistika (II izdanje) [Stylistics (2nd edition)]. Sarajevo, B\&H: Tugra.

Sarić, S. (in print). Govor i njegov jezik [Speech and his language]. 